\title{
Relationship of Compliance with Medication With hypertension
}

\author{
Abdur Rivai ${ }^{1}$, Nugrahadi Dwi Pasca Budiono ${ }^{2}$, Si'umiyati ${ }^{3}$. \\ ${ }^{1,2,3}$ Lecturer in Faculty of Health, Muhammadiyah University Gresik
}

\section{Article Info}

Article history:

Received Jun 09, 2020

Revised Jul 01, 2020

Accepted Jul 13, 2020

\section{Keywords:}

Hypertension, Drug Regularity, Elderly

\begin{abstract}
Elderly or Elderly is a group that due to age, physiological function of the body decreases due to the aging process so that non-communicable diseases get older and more diseases will appear in the elderly, and due to degenerative impairment occurs the body so it is susceptible to infectious diseases . Based on Riskesdas (2013), the most common diseases in the elderly are non-communicable diseases or PTM, namely Hypertension of $45.9 \%$ at age 55-64 years and 63.8\% at age 75 years above. The purpose of this study was to determine the relationship between regularity of taking drugs with hypertension. This type of research is correlation analytic research with observational observational and retrospective approaches. The study population is all elderly with hypertension in Karang Werda Sejahtera Kelurahan Bendul Merisi Surabaya, sample size 24, sampling with total sampling. Hypertension variable data collection is done by observing measurements and compliance variables using the MMAS-8 questionnaire or Morisky Medication Adherence Scale, spearmen correlation test data analysis with $\alpha=0,05$. The results obtained 1) there is a relationship between adherence to take antihypertensive medication with Hypertension with $\rho=$ $0.010,2)$ there is a relationship between knowledge of taking antihypertensive medication with Hypertension with $\rho=0.012$, 3) There is a relationship between motivation to take antihypertensive medication with Hypertension with $\rho=0.012$. Maintaining medication compliance is important to reduce morbidity and mortality in the elderly .
\end{abstract}

Copyright (C) 2020 University Muhammadiyah of Gresik. All rights reserved.

\section{Corresponding Author:}

\author{
Abdur Rivai \\ Lecturer in Faculty of Health, Muhammadiyah University Gresik \\ Street Sumatera 101 Gresik Kota Baru (GKB), Gresik - 61121. \\ Email: h.abdurrivai@umg.ac.id.
}




\section{PRELIMINARY}

\section{Background}

Elderly is a group that because of aging, the physiological function of the body decreases due to the aging process so that non-communicable diseases get older the more diseases that arise in the elderly. In addition there are problems due to degenerative decline in endurance so that the body is susceptible to infection infectious diseases. Based Riskesdas (2013) found most prevalent diseases in advanced age is a non-communicable diseases or NCDs. Most non-communicable diseases are hypertension, with details of $45.9 \%$ at age 55-64 years and $63.8 \%$ at age 75 years above, the problem of research problems is the high cases of hypertension in the elderly. Hypertension is an increase in systolic blood pressure of at least $140 \mathrm{mmHg}$ or diastolic pressure of at least $90 \mathrm{mmHg}$ (Sylvia \& Lorraine, 2005). Hypertension in a person occurs very slowly, so that patients do not experience complaints, and show no symptoms for years, this happens because the process of atherosclerosis occurs in blood vessels so that elasticity in the blood vessels decreases, which will increase blood pressure. In some cases, patients with hypertension have to comsumption drugs for a lifetime. Decrease dose or stop treatment can be performed if the patient's blood pressure was under control by changing the style of life. M engonsumsi drug doses prescribed and taken regularly is the key to successful treatment of hypertension. The research objective for know association between all compliance taking medication hypertension to hypertension in Werda Karang member of Prosperous sill Merisi Surabaya

\section{LITERATURE REVIEW}

\section{Elderly or Elderly}

According to RI Law number 13 of 1998 concerning Elderly Welfare or Elderly, what is meant by elderly is someone who has reached the age of 60 years and over. This is in line with the World Health Organization or WHO, Advanced age is a person who has aged 60 years and over. Advanced age is one age group on the human life cycle. Further groups of age this is a group that has entered the final stages of a phase of human life. Health problems at age further setback came from the body's cells, so that the function and endurance someone will decline, as well as risk factors for the disease will further increase. The problems found in advanced age, among others malnutrition, impaired balance, sudden confusion, other than that some diseases common in the elderly are hypertension, hearing loss, impaired vision, osteoporisis, diabetes mellitus and other diseases. Based on RI Law No. 36/2009 concerning Health, health care efforts for the elderly have the aim of maintaining healthy and productive lives both socially and economically. In addition to this the Government shall guarantee the availability of health services and facilitate further group of age to live independent and productive, both economically and socially.

\section{Hypertension}

Hypertension or high blood pressure is defined as an increase in systolic blood pressure of at least $140 \mathrm{mmHg}$ or diastolic pressure of at least $90 \mathrm{mmHg}$ (Sylvia \& Lorraine, 2005). Hypertension or high blood pressure is a state of increased systolic blood pressure greater than $140 \mathrm{mmHg}$ and or diastolic greater than $90 \mathrm{mmHg}$ at two measurements with an interval of 5 minutes in a state of sufficient rest (MOH, 2007). According to the Indonesian Ministry of Health (2016). classification of hypertension based on the cause, divided into 2 groups, namely 1) Essential hypertension or primary hypertension, namely unknown hypertension 2) Secondary hypertension is hypertension that can be determined approximately 10\%, namely kidney blood vessel abnormalities, thyroid gland disorders in the form of hyperthyroidism, adrenal gland disease in the form of hyperaldosteronism. Classification is based on Joint National Commit t e e VII or JNC- 
VII (2003) 1) Normal if systolic <120 mmHg and Diastole <80 mmHg, 2) Prehypertension if systolic 120-139 mmHg and 80-89 mmHg Diastole, 3) Hypertension Degrees I if Systole 140-159 mmHg and Diastole 90-99 mmHg, 4) Hypertension of Grade II if Systole $\geq 160$ $\mathrm{mmHg}$ and Diastole $\geq 100 \mathrm{mmHg}$. Prehypertension is not regarded as a category penyaki t, but identify patients who have blood pressure cend e rung to rise to the classification of hypertension in the future. There are two stages or stages of hypertension and all patients in this category must be given drug therapy (MOH, RI, 2006). Some healthy lifestyle that is recommended by many guidelines are as follows 1) Weight loss. Substitute unhealthy foods by increasing the intake of vegetables and fruits, 2) Reducing salt intake. Low-salt diet is also useful for reducing the dose of antihypertensive drugs in patients with grade II hypertension. It is advisable to salt intake does not exceed 2 grams am per day, 3) exercise, done regularly as many as 30 to 60 minutes per day, at least 3 days per week, can help decrease blood pressure, 4) Reduce consumption of alcohol. Consumption al k ohol more than 2 cups per day in men or one drink per day in women, can increase blood pressure, 5) Stop smoking. Although this has not yet been proven to have a direct effect on reducing blood pressure, smoking is one of the main risk factors for cardiovascular disease. Some types of antihypertensive drugs are as follows: Diuretics, beta blockers or beta-blockers, Angiotensin II receptor blockers or ARBs, calcium antagonists or calcium channel blockers, ACE inhibitors, Alpha-2 receptor agonists, alpha or alpha-blockers, renin inhibitors. According to PERKI (2015), pharmacological therapy in hypertension begins when in patients with first- degree hypertension who do not experience a decrease in blood pressure after more than 6 months undergoing a healthy lifestyle and in patients with second-degree or higher hypertension. Some basic principles of pharmacological therapy should be considered to maintain compliance and minimize side effects, namely 1) If possible, give medicine a single dose 2) Give the drugs generic or non-trademarked where appropriate, and can reduce costs, 3) Give the drug in patients lan jut age at the age of 80 years as the age of 55 to 80 years, taking into account comorbidities, 4) Do not combine the angiotensin converting enzyme inhibitors, or ACE-i to angiotensin II receptor blockers or ARBs, 5) Provide education thorough patient regarding pharmacological therapy, 6) Perform regular monitoring of drug side effects.

\section{Compliance with Medication}

Adherence or adherence or compliance is defined as an act of behavior of someone who gets treatment, follows, a diet, and implements a lifestyle in accordance with recommendations from health care providers (WHO in Hardiyatmi, 2016). According to Kozier (2010), Compliance is an individual's behavior, for example taking medication, adhering to a diet or making lifestyle changes, according to therapeutic and health recommendations. The level of compliance can range from disregarding or implementing any aspect of the recommendation to adhering to and carrying out the agreed plan. There are many factors that affect obedience. According to Kozier (2010), several factors that can affect adherence are 1) Motivation of patients to recover, 2) The level of lifestyle changes needed to cure patients, 3) Perception of severity of health problems, 4) Value of efforts to reduce the threat of disease, 5 ) Difficulty understanding and performing desired special behaviors, 6) Disease level of disease or series of therapies, 7) Belief that programmed therapy will help or not help healing, 8) Complexity, side effects experienced, 9) Certain cultural heritage that makes compliance becomes difficult, 10) Level of satisfaction and quality and type of relationship with health service provision. There are various kinds of tools developed in measuring compliance, one of which is known as the MMAS-8 or Morisky Medication Adherence Scale, which is a scale developed in the form of a questionnaire, which consists of 8 questions concerning compliance with taking 
medication. This questionnaire was developed to measure medication adherence in people with hypertension, and this questionnaire has been validated. In subsequent developments MMAS- 8 can also be used to measure the level of adherence to take medication in patients with other diseases. MMAS-8 is the result of the development of the MMAS-4 questionnaire that was discovered by Morisky in 1980. MMAS-4 was used as a simple assessment of one's drug-taking behavior (CMSA, 2006). As for how to vote on questions 1 through 7, if answered yes rated 0, whereas if the answer no rated 1. Question Number 8 has a Likert scale with a maximum value of 5 points, with the details if the answer is never or rarely rated 5 , if the answer is sometimes given a value of 4 , if the answer is sometimes given a value of 3 , if the answer is usually given a value of 2 , and if the answer is always or often given a value of 1 . So that the measurement value ranges from 1 to 12 . As for assessing the level of compliance is as following: 1) High level of compliance if it has a value of 8-12 , 2) Medium level of compliance if it has a value of 6-7, 3) Low level of compliance if it has a value of 1-5. This questionnaire can also assess motivation and knowledge. For questions number 1, 2 and 6 are questions about motivation which include the patient's ability to remember and his willingness to take drugs. While questions number 3,4,5 are knowledge questions that measure a patient's ability to assess the benefits to be gained if someone is taking drugs. A person with low motivation and low knowledge if has a value of 0 to 1, and has high motivation and high knowledge if has a value of 2 to 3 .

\section{RESEARCH METHODS}

This research is an analytic research observational approach and the correlation with retrospeksif approach, the population of the study is the whole elderly with hypertension in Werda Karang Sejahtera keluran sill Merisi Surabaya, sample size 24, sa mpling by means that total sampling. Hypertension variable data collection is done by observing measurements with 4 classifications 1) Normal if Systole $<120 \mathrm{mmHg}$ and Diastole $<80$ $\mathrm{mmHg}$, 2) Prehypertension if Sistole 120-139 $\mathrm{mmHg}$ and Diastole $80-89 \mathrm{mmHg}$, 3) Hypertension Degree if Systole 140 -159 mmHg and Diastole 90-99 mmHg, 4) Grade II hypertension if cystole $\geq 160 \mathrm{mmHg}$ and Diastole $\geq 100 \mathrm{mmHg}$. And the compliance variable using the MMAS-8 questionnaire conducted by interview, with 3 levels of compliance namely 1) High level of compliance if it has a value of 8-12,2) The level of compliance is moderate if it has a value of 6-7, 3) The level of compliance is low if it has a value of 1-5. For questions number 1,2 and 6 are questions about motivation with level 1) Motivation is high if it has a value of 2 to 3,2) Motivation is low if it has a value of 0 to 1. While questions number $3,4,5$ are questions of knowledge that measure ability patients in assessing the benefits to be gained if someone consumes drugs, with levels 1) High knowledge if it has a value of 2 to 3,2) Low knowledge if it has a value of 0 to 1 . Analyze data by using the Spearman correlation test with $\alpha=0,05$.

\section{RESULTS AND DISCUSSION \\ Research result}

1. Classification of Hypertension

Classification of Hypertension in Karang Werda Sejahtera Members.

\begin{tabular}{clcc}
\hline No & Classification of Hypertension & Frequency & Percentage (\%) \\
\hline 1 & Pre Hipertensi & 7 & 29 \\
2 & Hypertension Degrees I & 10 & 42 \\
3 & Hypertension Degrees II & 7 & 29 \\
\hline \multicolumn{2}{r}{ Totals } & $\mathbf{2 4}$ & $\mathbf{1 0 0}$ \\
\hline
\end{tabular}

Relationship of Compliance with Medication With hypertension .......(Abdur Rivai) 
Based on the table above, the most frequent classification of hypertension is first degree hypertension, which is 10 respondents or $42 \%$.

2. Compliance with Anti-Hypertension Medication

Compliance with anti-hypertension medication for Karang Werda Sejahtera Members.

\begin{tabular}{cllcc}
\hline No & & Obedience & Frequency & Percentage (\%) \\
\hline 1 & Low & & 7 & 29 \\
2 & Is & & 3 & 13 \\
3 & High & Totals & 14 & 58 \\
\hline \multicolumn{2}{r}{} & $\mathbf{2 4}$ & $\mathbf{1 0 0}$ \\
\hline
\end{tabular}

Based on the table above, adherence to taking anti-hypertension drugs is mostly high, namely 14 respondents or $58 \%$.

3. Knowledge of the Benefits of Taking Anti-Hypertension Medications

Knowledge of the benefits of taking anti-hypertensive medication for Members Karang Werda Sejahtera.

\begin{tabular}{ccccc}
\hline No & & Knowledge & Frequency & Percentage (\%) \\
\hline 1 & Low & & 6 & 25 \\
2 & High & & 18 & 75 \\
\hline \multicolumn{2}{r}{} & Totals & $\mathbf{2 4}$ & $\mathbf{1 0 0}$
\end{tabular}

Based on the table above, knowledge about the benefits of taking antihypertensive drugs is mostly high, namely 18 respondents or $75 \%$.

4. Motivation to Take Anti-Hypertension Medication

Motivation to take anti-hypertension medication for Karang Werda Sejahtera Members.

\begin{tabular}{ccccc}
\hline No & & Motivation & Frequency & Percentage (\%) \\
\hline 1 & Low & & 6 & 25 \\
2 & High & & 18 & 75 \\
\hline & & Totals & $\mathbf{2 4}$ & $\mathbf{1 0 0}$
\end{tabular}

Based on Table 4 above, the motivation of respondents to take anti-hypertension drugs was mostly high, namely 18 respondents or $75 \%$.

5. Relationship between Compliance with Medication and Hypertension

The relationship of adherence to taking antihypertensive medication and hypertension on Karang Werda Sejahtera member.

\begin{tabular}{|c|c|c|c|c|c|c|c|c|}
\hline \multirow{3}{*}{ Knowledge } & \multicolumn{6}{|c|}{ Hypertension } & \multirow{3}{*}{ Qty } & \multirow{3}{*}{$\%$} \\
\hline & \multicolumn{2}{|c|}{$\begin{array}{c}\text { Pre } \\
\text { Hypertension } \\
\end{array}$} & \multicolumn{2}{|c|}{$\begin{array}{c}\text { Hypertension } \\
\text { Degrees I }\end{array}$} & \multicolumn{2}{|c|}{$\begin{array}{c}\text { Hypertension } \\
\text { Degrees II }\end{array}$} & & \\
\hline & Freq & $\%$ & Freq & $\%$ & Freq & $\%$ & & \\
\hline Low & 0 & 0 & 2 & 33 & 4 & 67 & 6 & 100 \\
\hline \multirow[t]{2}{*}{ High } & 7 & 39 & 8 & 44 & 3 & 17 & 18 & 100 \\
\hline & 7 & 29 & 10 & 42 & 7 & 29 & 24 & 100 \\
\hline
\end{tabular}

Spearmen's rho correlation test $\rho=0.012, r=-0.504$

Based on the table above, most of the respondents who have low knowledge of taking drugs $(67 \%)$ with a class II hypertension classification, From the Spearmen's Test rho correlation $\rho=0.012<0.05$, so there is a relationship between the 
knowledge of taking drugs with hypertension, Correlatin Coefficient $r=-0.504$, meaning that the higher the knowledge of taking medicine the lower the degree of hypertension.

6. The Relationship between Motivation for Taking Medication and Hypertension

Relationship of motivation to take medication with hypertension in Members Karang Werda Sejahtera.

\begin{tabular}{|c|c|c|c|c|c|c|c|c|}
\hline \multirow{3}{*}{ Motivation } & \multicolumn{6}{|c|}{ Hypertension } & \multirow{3}{*}{ Qty } & \multirow{3}{*}{$\%$} \\
\hline & \multicolumn{2}{|c|}{$\begin{array}{c}\text { Pre } \\
\text { Hypertension } \\
\end{array}$} & \multicolumn{2}{|c|}{$\begin{array}{c}\text { Hypertension } \\
\text { Degrees I }\end{array}$} & \multicolumn{2}{|c|}{$\begin{array}{c}\text { Hypertension } \\
\text { Degrees II }\end{array}$} & & \\
\hline & Freq & $\%$ & Freq & $\%$ & Freq & $\%$ & & \\
\hline Low & 1 & 17 & 0 & 33 & 5 & 83 & 6 & 100 \\
\hline High & 6 & 33 & 10 & 56 & 2 & 11 & 18 & 100 \\
\hline & 7 & 29 & 10 & 42 & 7 & 29 & 24 & 100 \\
\hline
\end{tabular}

Based on the table above, the majority of respondents who have low motivation to take medicine or $83 \%$ with a classification of hypertension grade II. From the Spearmen's Test rho correlation $\rho=0.012<0,05$, so there is a relationship between motivation to take medication with hypertension, Correlatin Coefficient $r=-0.504$, meaning that the higher the motivation to take medication the lower the degree of hypertension.

\section{DISCUSSION}

\section{Classification of Hypertension}

The most frequent classification of hypertension is first degree hypertension, which is 10 respondents or $42 \%$. WHO data (2005) in the Ministry of Health (2019) 1 there are 1.13 billion in the world with hypertension, meaning that of 3 people there is 1 person diagnosed with hypertension, it is predicted that this number will continue to increase every year, and it is estimated that in 2025 there will be hypertension cases of 1.15 billion, and it is estimated that every year 10.44 million people die from hypertension and from complications from hypertension. According to the Ministry of Health (2019) pertensi Hypertension occurs in the age group 31-44 years by $31.6 \%$, ages $45-54$ years by $45.3 \%$, ages $55-65$ years by $55.2 \%$.

The elderly have a higher level of vulnerability to suffer from hypertension, this is caused by: 1) $\mathrm{M}$ akin gets older the higher the blood pressure, this is due to the process of thickening and stiffness of blood vessels due to the deposition of cholesterol, calcium, fibrous tissue $\mathrm{s}$ and so forth so that the blood vessels become elastic eventually lead to hypertension, 2) a diet that is uncontrolled and lead to overweight or even the occurrence of obesity, it is the initial trigger for the disease of high blood pressure, 3) Advanced age-prone high stress occurs, this is caused by physical setbacks, mental setbacks, psychological setbacks, social setbacks and economic setbacks. Even sometimes shunned by his own family, 4) As a result of physical deterioration, sporting events to be reduced, so that the heart is not trained to be able to work optimally, which eventually led to hipertensi.5) Besides advanced age prone to secondary hypertension, due to reduced heart function, kidney, hormonal systems and other systems.

WHO set every May 17 as World Hypertension Day, which aims to increase public awareness that hypertension is a disease that can be prevented and can be treated. For this the Republic of Indonesia's Ministry of Health has launched the 
CERDIK Programs, which is a health campaign to keep the heart and blood vessels healthy. Ingenious stands for $\mathrm{C}$ that checks the health berkal A, E, namely : Away with smoke, $\mathrm{R}$ is Diligently perform physical activity, $\mathrm{D}$ is healthy diet with caloric balance, I namely Rest c incense and $\mathrm{K}$ is the Manage stress.

2. Compliance with Medication

Obedience taking antihypertensive medication at Werda Karang Sejahtera members, the majority or $58 \%$ is high. According to the Ministry of Health (2019) the reasons for patients not taking medication include 1) hypertension sufferers feel healthy so that they do not need to take medication at $59.8 \%$, 2) Irregular visits to health care facilities to seek treatment by $31.3 \%, 3$ ) Taking traditional medicine which is widely available in the territory of Indonesia at $14.5 \%$, 4) Using other therapies besides pharmacotherapy at $12.5 \%, 5)$ Forgot to take medication at $11.5 \%, 6)$ Unable to buy hypertension medication at $8.1 \%, 7)$ There are side effects when taking antihypertension drugs by $4.5 \%, 8)$ anti-hypertension drugs are not available in health care facilities by $2 \%$. Meanwhile, according to Rano K Research (2018) the level of compliance with hypertension treatment in first-level health facilities is $53,5 \%$. RI Ministry of Health (2019) $)^{2}$, also campaigned to control hypertension with OBUH which is an abbreviation of $\mathrm{P}$, which is to routinely check health and follow doctor's advice, $\mathrm{A}$ is to overcome the disease with proper and regular treatment, $\mathrm{T}$ is to maintain a balanced diet with nutrition, $\mathrm{U}$ is to try to physical activity safely, $\mathrm{H}$ ie Avoid cigarette smoke, alcohol and other carcinogenic substances. Some factors that can cause old age to have a reduced level of adherence to take anti-hypertensive drugs include: 1) A person's memory, the older the more diminished. Old age is easy to forget new things including new things to take anti-hypertensive medication, but the past events still have a strong memory ,2) The length of time undergoing treatment, so that there is a feeling of being bored taking medication, feeling already healed so there is no need to take medication antihypertensive, 3) $\mathrm{T}$ heododanya traditional natural remedies, cheap although the efficacy is unknown, including the dose, including celery leaves, cat's whiskers, gotu kola, pace fruit, star fruit and so on.

3. Knowledge of the Benefits of Taking Anti-Hypertension Medications

Based on table above, the knowledge of the benefits of taking anti-hypertensive drugs most of the members of the Karang Wada Sejahtera group was high, namely 18 respondents or $75 \%$. Hanny, et al (2018), obtained in advanced age who have a good knowledge of hypertension by $46 \%$. Compared with Hany's research, knowledge about the benefits of taking medicine on Karang Werda Sejahtera members is higher, this is likely due to general high school education and above amounting to $67 \%$. Knowledge is influenced by several factors, namely one's education both formal and non-formal education, work done every day, experience, one's age, culture carried out every day, one's interest in something, exposure to information obtained and the availability of media.

4. Motivation for Taking Medication

Based on Table above, the motivation of taking antihypertensive medication majority or $75 \%$ is high. Motivation is the strength or energy of someone who can cause a level of persistence and great enthusiasm in carrying out an activity, either originating from within the individual itself or intrinsic motivation or originating from outside the individual or extracurricular motivation. In the MMAS-8 questionnaire the motivation assessment uses questions number 1,2 and 6. This assessment emphasizes more on internal motivation, so most of them already have motivation that comes from within 
the individual, but there are still $25 \%$ who have less internal motivation, so this group needs to be given motivation that comes from outside, including through Karang Werda activities Prosperous.

5. The relationship of medication adherence with hypertension

The results showed a significant relationship between compliance with medication with hypertension $(\rho=0.010)$ with $r=-0.514$ meaning that the relationship included a strong correlation because it was located between more than 0.5 to 0.75 . Negative correlation coefficient means the relationship between the two variables is not in the same direction, if adherence to taking medication is high then hypertension decreases. According to Rano K, et al (2018), there is a significant correlation between controlled and uncontrolled blood pressure and respondent compliance with p-0,000. Khairul Andar, et al (2019) There is a relationship between adherence to take antihypertensive medication with systolic blood pressure with $\mathrm{p}=0,000$ and diastolic blood pressure with $\mathrm{p}=0,000$. Compliance which is often referred to as compliance or adhere is a measure used to assess patients or sufferers in carrying out instructions and advice given by doctors and other health workers. Doctors in providing treatment will determine the type of single drug or combination, the dose of each medication, the dose that must be given for one day or 24 hours, the frequency of taking the drug in a day and the length of time needed to take medication. The level of adherence to take anti-hypertensive medication is the key to the success of treatment, because disobedience to the advice and advice of a doctor will result in treatment failure, the patient does not experience healing, maybe even the patient will experience complications that lead to the death of the patient.

6. Relationship of the benefits of taking medication with hypertension

The results showed a significant relationship between knowledge of taking medication with hypertension $\rho=0.012$ with $r=-0.504$ meaning that the relationship included a strong correlation because it was located between more than 0,5 to 0.75 . Negative correlation coefficient means the relationship between the two variables is not in the same direction, if knowledge of taking medication is high then hypertension decreases.

Based on the research of Jayanti et al (2013), there was a relationship between knowledge about hypertension and blood pressure control with $\mathrm{p}=0.019$. According to the research of Valdano et al (2016) there is a relationship between public knowledge and the incidence of hypertension, with $p=0,000$. According to Lewrence Green in Soekidjo (2015). Behavior is influenced by 3 factors, namely Predisposing Factors, Enabling Factors and Reinforcing Factors. Knowledge, in this case is knowledge about the benefits of taking antihypertensive drugs is one of the predisposing factors or factors that influence or factors that give a tendency to carry out behavior, which in this case the behavior of taking medication. From the behavior of taking good medicine will affect one's health status in this case the control of blood pressure in people with hypertension, so that knowledge indirectly affects one's blood pressure or hypertension.

7. Relationship of motivation to take medicine with hypertension

The results showed a significant relationship between motivation to take medication with hypertension $\rho=0.012$ with $r=-0.504$ meaning that the relationship included a strong correlation because it was located between more than 0.5 to 0.75 . Negative correlation coefficient means the relationship between the two variables is not in the same direction, if the motivation to take medication is high then hypertension 
decreases. According to Nuri Novianti (2012). There is a relationship between the patient's intrinsic motivation in carrying out blood pressure control with the occurrence of recurrent hypertension with a p-value of 0,00. According to Yossi and Rian Okta (2014). There was a significant relationship between motivation and hypertension client compliance in undergoing treatment at Talang Health Center, Solok Regency in 2014, with $p=0,000$. Motivation is the urge that comes from within a human being to take certain actions or behavior. The need to recover from a hypertension, according to Maslow's Motivation theory (1943) is included in physiological or physical needs. A person's health status is something that is fundamentally needed, without health something that would be meaningless, without health we cannot do something. Motivation to recover must be supported by motivation to carry out regular checks, take medication according to the dose and time determined, even taking anti-hypertensive medication can be done for a lifetime in certain people.

\section{CONCLUSIONS AND RECOMMENDATIONS Conclusion}

The conclusions of this study are 1) The biggest classification of hypertension or $42 \%$ is hypertension degree I, 2) Compliance with most anti-hypertensive drugs or 58\% with high levels of compliance, 3) Knowledge of the benefits of taking anti-hypertensive drugs mostly or $75 \%$ with a high level of knowledge, 4) Motivation to take anti-hypertension drugs mostly or $75 \%$ with a high level of motivation, 5) There is a relationship between adherence to take anti-hypertension drugs with Hypertension with $\rho=0.010,6$ ) There is a relationship between knowledge of taking anti-hypertension drugs with Hypertension with $\rho=0.012$, 7) There is a relationship between motivation to take anti-hypertensive medication with Hypertension with $\rho=0.012$.

\section{Suggestion}

For health workers to always improve health promotion in the control of hypertension so that the community always conducts SMART and COMULAR behavior. To prevent the occurrence of hypertension and complications of hypertension need a health check among other measurements of blood pressure on a regular basis. The activities of Karang Werda Sejahtera need to be continued in order to protect the health of Karang Werda Sejahtera members. PHC need to improve health services to the advanced ages, especially members Werna Karang Sejahtera.

\section{BIBLIOGRAPHY}

[1] CMSA, 2006, Case Management Adherence Guidelines Version 2.0., www.cmsa.org, Diakses pada tanggal 10 Desember 2019.

[2] Hannys Shely Permata Sari, Joko Wiyono, Ragil CaturAdi W. Hubungan Tingkat PengetahuanLansia Tentang Hipertensi Dengan KepatuhanDalam Minum Obat di Posyandu Lansia Drupadi. Jurnal Nursing New, Volume 3, Nomor 1, Tahun 2018. https://publikasi.unitri.ac.id. Diakses pada tanggal 10 Desember 2019.

[3] Jayanti Wulansari, Burhannudin Ichsan, Devi Usdiana. 2013. Hubungan Pengetahuan tentang Hipertensi dengan Pengendalian Tekanan Darah pada Pasien Hipertensi di Poliklinik Penyakit Dalam RSUD dr.Moewardi Surakarta. Jurnal Biomedika, Volume 5 Nomor 1, Februari 2013. file:///C:/Users/Asus\%20\%20PC/Downloads/271-2118-1-PB.pdf. Diakses pada tanggal 10 Desember 2019. 
[4] Jonathan Sarwono. 2018. Mengenal apa itu Analisis Korelasi. www.jonathansarwono.info>korelasi. Diakses pada tanggal 17 Mei 2020

[5] Kementerian Kesehatan RI. 2016². Situasi Lanjut Usia (Lansia) di Indonesia. InfoDatin, Pusat Data dan Informasi Kementerian Kesehatan RI, Pedoman Nasional Promosi Kesehatan. Jakarta : Kementerian Kesehatan Republik Indonesia

[6] Kementerian Kesehatan RI. 2016². Pedoman Teknis dan Tata Laksana Hipertens

[7] Kementerian Kesehatan RI. 2019'. Hari Hipertensi Dunia 2019: "Know Your Number, Kendalikan Tekanan Darahmu dengan Cerdik. https://p2ptm.kemkes.go.id. Diakses tanggal 17 Mei 2020.

[8] Kementerian Kesehatan RI. 2019². Kendalikan Hipertensi dengan Patuh. Apa Itu Patuh. https:// https://p2ptm.kemkes.go.id. Diakses tanggal 17 Mei 2020.

[9] Khairul Anwar, Rusni Masnina, Hubungan Kepatuhan Minum ObatAnti Hitertensi Dengan Tekanan Darah Pada Lansia Penderita Hipertensi di Wilayah Kerja Puskesmas Air Putih Samarinda. https://jurnal.umkt.ac.id. Diakses tanggal $17 \mathrm{Mei}$ 2020.

[10] Kozier. 2010. Buku Ajar Praktek Keperawatan Klinis. Edisi 5. Jakarta: EGC.

[11] Nuri Novianti, Sri Mulyati Rahayu, Yuyun Sarineng. 2012. Hubungan Motivasi Intrinsik Pasien Dalam Melaksanakan Kontrol Tekanan Darah Dengan Kejadian Hipertensi Berulang Di Puskesmas Cibiru Tahun 2012. Jurnal Bhakti Kencana Medika, Volume 2, No. 4, September 2012. file:///C:/Users/Asus\%20\%20PC/Downloads/hub\%20motivasi\%20intrinsik.pdf. Diakses pada tanggal 10 Desember 2019.

[12] PERKI. 2015. Pedoman Tatalaksana Hipertensi Pada Penyakit Kardiovaskuler.

[13] Prov Jatim. 2017. Peraturan Gubernur Provinsi Jawa Timur Nomor 31 Tahun 2017 tentang Karang Werda. https://peraturan.bpk.go.id. Diakses tanggal 15 November 2019.

[14] Rano K. Sinuraya, Dika P. Destiani,Irma M. Puspitasari, Ajeng Dianini. Tingkat Kepatuhan Pasien Hipertensi di Fasilitas Kesehatan Tingkat Pertama di Kota Bandung. Jurnal Farmasi Klinik Indonesia. Vol 7no 2, hlm 124-133, Juni 2018. https://jurnal.unpad.ac.id. Diakses 17 Mei 2020.

[15] Soekidjo Notoatmodjo. 2015. Ilmu Kesehatan Masyarakat, Prinsip-Prinsip Dasar. Jakarta : PT Rineka Cipta.

[16] Soekidjo Notoatmodjo. 2017. Ilmu Perilaku Kesehatan. Jakarta : PT Rineka Cipta.

[17] Sylvia A Priceand Lorraine M Wilsin. 2005. Patofisiologi- Konsep Klinis ProsesProses Penyakit, Edisi 6, Volume 1, Jakarta: EGC.

[18] Valdano A Limbong, Adisti Rumayar, Grace D. Kandou (2016). Hubungan Pengetahuan dan Sikap dengan Kejadian Hipertensi di Wilayah Kerja Puskesmas Tateli Kabupaten Minahasa. Jurnal KESMAS, Volume 7 Nomor 4, 2016. file:///C:/Users/Asus\%20-\%20PC/Downloads/23122-47172-1-SM.pdf. Diakses pada tanggal 10 Desember 2019.

[19) Yossi Fitrina dan Rian Okta Haryoko. 2014. Hubungan Karakteristik dan Motivasi Pasien Hipertensi Terhadap Kepatuhan Dalam Menjalani Pengobatan Di Puskesmas Talang Kabupaten Solok Tahun 2014. Ejurnal Stikes. Yarsi. 
http://www.ejournal.stikesyarsi.ac.id/index.php/JAV1N1/article/viewFile/51/104. Diakses pada tanggal 10 Desember 2019. 